\title{
The Relationship Between the Physical Activity Level and Fatigue Perception, Quality of Life and Psychological Status in Patients with Obstructive Sleep Apnea Syndrome
}

\author{
Obstrüktif Uyku Apne Sendromu Hastalarında Fiziksel Aktivite Seviyesi ve Yorgunluk \\ Algılaması, Yașam Kalitesi ve Psikososyal Statü Arasındaki Ilișki
}

\author{
(D) Hakan Çalışkan, (1) Nurel Ertürk*, (1) Ebru Çalık Kütükçü**, (1) Hülya Arıkan**, (D) Naciye Vardar Yağlı** , (D) Melda Sağlam** , \\ (D) Hikmet Fırat***, (1) Sadık Ardıç****, (D) Deniz İnal İnce**, (D) Melike Yüce Ege*** \\ University of Health Sciences, Dışkapı Yıldııım Beyazıt Training and Research Hospital, Clinic of Neurology, Intensive Care Unit, Ankara, Turkey \\ *University of Health Sciences, Trabzon Ahi Evren Thoracic and Cardiovascular Surgery Training and Research Hospital, Cardiopulmonary Rehabilitation \\ Unit, Trabzon, Turkey \\ * Hacettepe University Faculty of Health Sciences, Department of Physiotherapy and Rehabilitation, Ankara, Turkey \\ ***University of Health Sciences, Dışkapı Yıldırım Beyazıt Training and Research Hospital, Clinic of Chest Diseases, Ankara, Turkey \\ ****Koru Ankara Hospital, Clinic of Chest Diseases and Sleep Center, Ankara, Turkey
}

\begin{abstract}
Objective: Currently, there is a need for research that examines factors which affect physical activity (PA) participation in Obstructive Sleep Apnea syndrome (OSAS) patients. The purpose of this study was to investigate the relationship between the PA level and daytime sleepiness, fatigue perception, quality of life, and psychological status in patients with OSAS.

Materials and Methods: This cross-sectional study involved 38 patients with OSAS between the ages of 30-60 years. The PA level was determined using the Turkish version of the International Physical Activity Questionnaire (IPAQ). Quality of life was evaluated by the Functional Outcomes of Sleep Questionnaire and Nottingham Health Profile (NHP). The Epworth Sleepiness Scale (ESS) was used for evaluation of the sleepiness status. The fatigue perception of the patients was evaluated by the Fatigue Impact Scale (FIS) and the Fatigue Severity Scale (FSS). Results: According to IPAQ classification, $44.7 \%$ of patients were inactive. A marked correlation was observed between IPAQ-total score with ESS score $(r=-0.493, p=0.002)$, Hospital Anxiety and Depression Scale-Anxiety score $(r=-0.338, p=0.041)$, NHP-social isolation score $(r=-0.406, p=0.013)$, FIS-physical score $(r=-0.404, p=0.013)$, and FISpsychosocial score $(r=-0.411, p=0.012)$.

Conclusion: This study showed that the total amount of PA in patients with OSAS is closely related to excessive daytime sleepiness, anxiety level, social isolation and effects of fatigue on physical and psychosocial functions.

Keywords: Obstructive sleep apnea, apnea-hypopnea index, exercise test, anxiety, sedentary lifestyle
\end{abstract}

Öz

Amaç: Obstrüktif Uyku Apne sendromu (OSAS) hastalarında fiziksel aktivite (PA) katılımını etkileyen faktörleri inceleyen araştırmalara ihtiyaç vardır. Bu çalışmanın amacı, OSAS'li hastalarda PA düzeyi ile gündüz uyku hali, yorgunluk algısı, yaşam kalitesi ve psikolojik durum arasındaki ilişkiyi araştırmaktır.

Gereç ve Yöntem: Bu kesitsel çalışma, 30-60 yaşları arasında 38 OSAS'li hastayı kapsamaktadır. PA seviyesi, Uluslararası Fiziksel Aktivite Anketinin (IPAQ) Türkçe versiyonu kullanılarak belirlendi. Yaşam kalitesi Uykunun Fonksiyonel Sonuçları Ölçeği ve Nottingham Sağlık Profili (NHP) ile değerlendirildi. Uykululuk durumunu değerlendirmek için Epworth Uykululuk Ölçeği (EUÖ) kullanıldı. Yorgunluk algısı Yorgunluk Etki Ölçeği (FIS) ve Yorgunluk Şiddeti Ölçeği (FSS) ile değerlendirildi.

Bulgular: IPAQ sınıflandırmasına göre, hastaların \%44,7'si inaktifti. IPAQ-total skoru ile EUÖ skoru $(r=-0,493, p=0,002)$; Hastane Anksiyete ve Depresyon Ölçeği-A skoru ( $r=-0,338, p=0,041)$; NHP-sosyal izolasyon puanı $(r=-0,406, p=0,013)$; FIS-fiziksel skoru $(r=-0,404, p=0,013)$ ve FISpsikososyal skoru $(r=-0,411, p=0,012)$ arasında belirgin bir korelasyon gözlendi.

Sonuç: Bu çalışma, OSAS'li hastalarda toplam PA miktarının aşırı gündüz uykululuk hali, kaygı düzeyi, sosyal izolasyon ve yorgunluğun fiziksel ve psikososyal işlevler üzerindeki etkileriyle yakından ilişkili olduğunu göstermiştir.

Anahtar Kelimeler: Obstrüktif uyku apnesi, apne-hipopne indeksi, egzersiz testi, anksiyete, sedanter yaşam tarzı

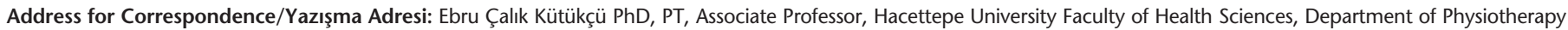
and Rehabilitation, Ankara, Turkey Phone: +90 31230525 25/195 E-mail: ebrucalk85@hotmail.com ORCID-ID: orcid.org/0000-0001-5215-5125 Received/Geliş Tarihi: 23.10.2018 Accepted/Kabul Tarihi: 13.01.2019 


\section{Introduction}

Obstructive Sleep Apnea syndrome (OSAS) is a common disorder characterized by repetitive episodes of breathing cessation during sleep that leads to poor quality of sleep $(1,2)$. Physical inactivity is strongly associated with some of OSAS risk factors like obesity $(1,3)$. The exercise training programs are especially recommended in these patient group due to positive impact on the inflammatory profile, disease severity and improvement of metabolic syndrome $(3,4)$.

Respiratory effort-related arousals are thougth to be responsible for lower sleep efficiency, excessive daytime sleepiness and fatigue in patients with OSAS (1). Fatigue, tiredness, or lack of energy complaints may be as important as that of sleepiness in OSAS and they are more frequent in women than men (5). Depressive symptoms are common in up to $50 \%$ of patients with OSAS (1). In addition, higher levels of depressive symptoms were found to be related with greater levels of fatigue in OSAS (6).

Individuals with OSAS have decrease in physical activity (PA) participation (7-9). The most common clinical outcomes of OSAS like excessive daytime sleepiness, fatigue, depression, functional and cognitive decline can increase the duration of sedentary time. Currently, there is some knowledge on the amount of PA in individuals with OSAS and potential factors that is related with amount of PA and sedentary time $(7,9)$ but there is little data about the relationship between the PA level and fatigue, daytime sleepiness, quality of life and psychological status. There is a need for research that examines patterns and factors that affect PA participation in OSAS patients. Therefore, the purpose of this study was to investigate the relationship between the PA level and daytime sleepiness, fatigue perception, quality of life and psychological status in patients with recently diagnosed OSAS.

\section{Materials and Methods}

\section{Participants}

The research was performed in Hacettepe University Faculty of Health Sciences, Department of Physiotherapy and Rehabilitation. The study has been approved by the Hacettepe University Ethics Committee no: GO 18/491. Participants were informed about the study and their written informed consents were collected prior to study. This cross-sectional study included 38 patients with OSAS between 30-60 years old diagnosed by the Department of Chest Diseases and Sleep Center, University of Health Sciences, Ankara Dışkapı Yıldırım Beyazıt Training and Research Hospital. Individuals who could be cooperative for measurements and questionnaires and have stable general health status included in the study. Patients with a neurological, orthopedic or psychological disease that may affect assessments and have chronic diseases like diabetes mellitus, chronic obstructive pulmonary disease (COPD) and asthma, patients whose medical condition is dangerous for exercise, patients with body mass index (BMI) $40 \mathrm{~kg} / \mathrm{m}^{2}$ or more were excluded. None of patients were on continuous positive airway pressuretherapy, because all of them were directed shortly after the diagnosis and evaluated.

\section{Assessments}

Physical data (age, height, weight) were recorded. BMI was calculated as body weight/height ${ }^{2}\left(\mathrm{~kg} / \mathrm{m}^{2}\right)$. BMI was classified like underweight $\left(<18.5 \mathrm{~kg} / \mathrm{m}^{2}\right)$, normal $\left(18.5-24.99 \mathrm{~kg} / \mathrm{m}^{2}\right)$, overweight $\left(>25 \mathrm{~kg} / \mathrm{m}^{2}\right)$ and obese $\left(>30 \mathrm{~kg} / \mathrm{m}^{2}\right)$ (10). Smoking history was recorded as pack-years. Symptoms of individuals related to OSAS were questioned and recorded.

All patients underwent polysomnography (PSG). All PSG recordings included electroencephalogram, electrooculogram, and submental and bilateral anterior tibialis electromyogram using surface electrodes. They also included recordings of airflow (using thermistors), arterial oxygen saturation $\left(\mathrm{SpO}_{2}\right)$ (using pulse oximetry), abdominal and thoracic respiratory movements (using thoracoabdominal inductance plethysmography), electrocardiogram body position, and snoring. The sleep stages were analysed using an agreed criteria developed by Hori et al. (11). Respiratory events and other related events were scored using the American Academy of Sleep Medicine Task Force criteria (12). An apnoea was defined as complete cessation of airflow for at least $10 \mathrm{~s}$. A hypopnoea was defined as a reduction in airflow by more than $50 \%$ from baseline for at least $10 \mathrm{~s}$ in association with a fall in arterial $\mathrm{SpO}_{2}$ of at least $3 \%$. The term apnea-hypopnea index (AHI) was described as the number of apnoea plus hypopnoea per hour of sleep (13). The patients were divided to three groups according to their $\mathrm{AHI}$ scores like: mild OSAS (AHI <15/hr), moderate OSAS (AHI between 15 and $30 / \mathrm{hr}$ ) and severe OSAS (AHI $\geq 30 / \mathrm{hr}$ ). AHI, oxygen desaturation index, $\mathrm{AHI}$ during rapid eye movement (REM) period of sleep $(\mathrm{AHI} \mathrm{REM}), \mathrm{AHI}$ during non-REM period of sleep $\left(\mathrm{AHI}_{\mathrm{NREM}}\right)$, apnea index, hypopnea index, mean heart rate and $\mathrm{SpO}_{2}$ during sleep, sleep efficiency, number of arousals, arousal index, apnea and hypopnea duration were recorded from (PSG).

Patients' circumference measurements (neck, waist, abdomen, hip) were made with a tape measure and waist/hip ratio was calculated (14). Fat mass (FM) and fat free mass (FFM) was determined using the skinfold method (Skinfold Caliper, Holtain Ltd, Crosswell, UK) from biceps, triceps, subscapular, and suprailiac regions. Measurements were repeated three times and the mean of three measurements was used (15).

The PA level was determined using the Turkish version of the International Physical Activity Questionnare (IPAQ). This is a seven-item questionnaire consisting of list of activities, and requests estimates of the duration and frequency for each activity engaged in over the previous 7 days. Scores for moderate and vigorous activities and walking were calculated as the sum of the corresponding item scores in terms of duration multiplied by known metabolic equivalents per activity. The sitting question is a separate score and is not included in the PA score (16).

The 6 minute walk test (6MWT) is a self-paced test of walking capacity. Patients were requested to walk as far as possible in 6 minute along a flat corridor. Standardised instructions and encouragement are commonly given during the test. The test was administered twice in the same day with a half-hour interval. The distance in metres is recorded. The 6MWT distance was expressed as percentages of the expected values from age and sex (6MWT\% of distance) (17). 
Health-related quality of life was evaluated by generic Turkish version of the Nottingham Health Profile (NHP) and diseasespesific the Functional Outcomes of Sleep Questionnare (FOSQ) Turkish version. The NHP is a useful patient-reported outcome for determining impact of chronic disease on patients that contains 38 statements of six subdimensions (energy, pain, emotional reactions, sleep, social isolation and physical mobility). The score of each dimensions ranges from 0-100. Higher scores indicate higher quality of life impairment (18). The FOSQ assesses the impact of excessive daytime sleepiness on physical, mental and social functioning in everyday activities. It consists total 26 items on four areas: activity level (9 questions), vigilance (7 questions), general productivity (8 questions) and social outcome (2 questions). The questions have responses on a 4 point scale (no difficulty, a little, moderate, or extreme). Total score is obtained by summing the scores of all items. Lower scores indicates greater dysfunctionality and worse quality of life (19).

The Epworth Sleepiness Scale (ESS) was used for evaluating sleepiness. The patients are asked to rate their likelihood of falling asleep in eight everyday situations over the previous month on a scale of 0-3. The ESS score is calculated by summing the eight item scores and ranges from 0 to 24 . The higher ESS scores indicate greater daytime sleepiness (20).

The fatigue perception of the patients were evaluated by the Fatigue Impact Scale (FIS) and the Fatigue Severity Scale (FSS). FIS is a multidimensional scale consisting of 40 questions to evaluate the patient's perception of the limitations caused by fatigue during the last month in the physical (10 items), cognitive (10 items) and psychosocial (20 items) functions. Total score ranges between 0 and 160. High scores indicate a higher effect of fatigue on daily life (21). The FSS is one of the most frequently used 9-item scale developed for evaluating fatigue. Patients are asked to provide a score for each item on a range from 1 (strongly disagreement) to 7 (strongly agreement), a score of $\geq 4$ indicates severe fatigue (22).

Psychosocial status of patients was assessed with Turkish version of the Hospital Anxiety and Depression Scale (HADS). The HADS is divided into two subscales to measure anxiety (HADS-A) and depression (HADS-D) during the past week. Total subscale scores range from 0 to 21. Cut off points for HADS-A score is 10 or more, and HADS-D score is 7 or more. Higher scores shows better psychosocial status (23).

\section{Statistical Analysis}

All analyses were performed using the Statistical Package for the Social Sciences (version 18.0) for Windows (24). For categorical variables, number (n) and percentage (\%) are presented, and for continuous variables, the mean and standard deviation are presented. The variables were investigated using visual (histograms/probability plots) and Shapiro-Wilk test to determine whether or not they are normally distributed. Correlations were analyzed using the Spearman correlation analysis because data was under non-parametric conditions (25). Correlations were classed as "strong" ( $r>0.70)$, "moderate" $(r=0.50-0.69)$, "weak" $(r=0.26-0.49)$, and "very weak or no correlation" ( $r=0.00-0.25)$ (26). Statistical tests were two-tailed and $\mathrm{p}<0.05$ was considered statistically significant (25).

\section{Results}

Table 1 has shown the characteristics of the patients. Twelve patients $(31.6 \%)$ were in the mild OSAS group, eleven patients (28.9\%) were in the moderate OSAS group and fifteen patients (39.5\%) were in severe OSAS group. According to BMI classification, $2.6 \%$ of patients was normal, $39.5 \%$ of patients was overweight and $57.9 \%$ of patients was obese. Mean FM percentage of patients was $33.8 \pm 5.7$ and median FFM percentage of patients was 57.9 (Table 1).

Distribution of symptoms related with OSAS was like following: $60.5 \%$ of patients had debility, $65.8 \%$ of patients had forgetfulness, $39.5 \%$ of patients had decision-making difficulty, $63.2 \%$ of patients had night sweating, $44.7 \%$ of patients had lack of concentration, $65.8 \%$ of patients had dry mouth, $23.7 \%$ of patients had morning headache, $42.1 \%$ of patients had memory weakness, $50 \%$ of patients feeling of suffocation during sleep and $97.4 \%$ of patients snore.

According to IPAQ categorical classification, 17 (44.7\%) patients were inactive, $14(36.8 \%)$ patients were minimally active, and seven $(18.4 \%)$ patient was sufficiently active in our study. Mean 6MWT distance was $621.9 \pm 49.5 \mathrm{~m}$. and mean percentage of $6 \mathrm{MWT}$ that they reached according to their age and sex was 104.5 $\pm 9.5 \%$ (Table 2).

\begin{tabular}{|c|c|}
\hline \multicolumn{2}{|l|}{ Variables } \\
\hline Age (years) & $46.2 \pm 7.9$ \\
\hline BMI $\left(\mathrm{kg} / \mathrm{m}^{2}\right)$ & $30.4 \pm 3.9$ \\
\hline $\mathrm{AHI}$ & $26.9(6-85.9)$ \\
\hline ODI & $16.4(5.2-82.5)$ \\
\hline $\mathrm{AHI}_{\mathrm{REM}}$ & $25.7(0-88.2)$ \\
\hline $\mathrm{AHI}_{\text {NREM }}$ & $25.4(2.4-86)$ \\
\hline $\mathrm{Al}$ & $4.5(0.2-48.5)$ \\
\hline $\mathrm{HI}$ & $21.3(5-85.2)$ \\
\hline Apnea duration (seconds) & $13.9(0.4-27.5)$ \\
\hline Hypopnea duration (seconds) & $21.7(11.1-31.6)$ \\
\hline Sleep efficiency (\%) & $100(47.6-98.5)$ \\
\hline Arousal (n) & $332(0-644)$ \\
\hline Arousal index & $53.1(0-96.7)$ \\
\hline $\mathrm{SpO}_{2}(\%)$ mean during sleep & $92(84-95.6)$ \\
\hline HR (beats/min) mean during sleep & $66(51-92)$ \\
\hline Neck circumference $(\mathrm{cm})$ & $40(37-47)$ \\
\hline Waist circumference $(\mathrm{cm})$ & $101.4 \pm 9.5$ \\
\hline Abdomen circumference $(\mathrm{cm})$ & $105.9 \pm 10.0$ \\
\hline Hip circumference $(\mathrm{cm})$ & $107.3 \pm 7.2$ \\
\hline Waist/hip ratio & $0.9 \pm 0.1$ \\
\hline FM (\%) & $33.8 \pm 5.7$ \\
\hline FFM (\%) & $57.9(37.2-90.2)$ \\
\hline \multicolumn{2}{|c|}{$\begin{array}{l}\text { BMI: Body mass index, AHI: Apnea-hypopnea index, ODI: Oxygen desaturation } \\
\text { index, REM: Rapid eye movement, NREM: Non-rapid eye movement, Al: } \\
\text { Apnea index, HI: Hypopnea index, SpO } \mathrm{Sp}_{2} \text { Oxygen saturation, HR: Heart rate, } \\
\text { FM: Fat mass, FFM: Fat free mass, min: Minutes }\end{array}$} \\
\hline
\end{tabular}




\begin{tabular}{|c|c|}
\hline \multicolumn{2}{|l|}{ Variables } \\
\hline IPAQ-vigorous PA score (MET-min/week) & $0(0-5760)$ \\
\hline IPAQ-moderate PA score (MET-min/week) & $0(0-2880)$ \\
\hline IPAQ-walking PA score (MET-min/week) & $643.5(0-2970)$ \\
\hline IPAQ-total PA score (MET-min/week) & $990(0-8232)$ \\
\hline IPAQ-sitting score (min) & $336(120-900)$ \\
\hline 6MWT distance $(\mathrm{m})$ & $621.9 \pm 49.5$ \\
\hline \%6 MWT & $104.5 \pm 9.5$ \\
\hline ESS score $(0-24)$ & $9.9 \pm 5.9$ \\
\hline NHP-energy score & $24(0-100)$ \\
\hline NHP-pain score & $0(0-54)$ \\
\hline NHP-emotional reactions score & $21.3(0-80.9)$ \\
\hline NHP-sleep score & $12.6(0-100)$ \\
\hline NHP-social isolation score & $0(0-100)$ \\
\hline NHP-physical mobility score & $11.5(0-63.2)$ \\
\hline NHP-total score $(0-100)$ & $113.5(0-259.2)$ \\
\hline FOSQ-activity level score & $2.9 \pm 0.6$ \\
\hline FOSQ-vigilance score & $2.6 \pm 0.8$ \\
\hline FOSQ-general productivity score & $3.13(0.75-4)$ \\
\hline FOSQ-social outcome score & $3.5(0-4)$ \\
\hline FOSQ-total score (5-20) & $11.7 \pm 2.7$ \\
\hline FIS-physical score & $8(0-35)$ \\
\hline FIS-cognitive score & $10.6 \pm 8.0$ \\
\hline FIS-psychosocial score & $16(0-63)$ \\
\hline FIS-total score (0-160) & $33(0-131)$ \\
\hline FSS score (0-7) & $4.1 \pm 1.6$ \\
\hline HADS-A score & $6.7 \pm 3.5$ \\
\hline HADS-D score & $5.6 \pm 3.3$ \\
\hline HADS-total score $(0-42)$ & $12.3 \pm 6.4$ \\
\hline \multicolumn{2}{|c|}{$\begin{array}{l}\text { IPAQ: International Physical Activity Questionnare, 6MWT: } 6 \text { minute walk } \\
\text { test, ESS: Epworth Sleepiness Scale, NHP: Nottingham Health Profile, FOSQ: } \\
\text { Functional Outcomes of Sleep Questionnare, FIS: Fatigue Impact Scale, FSS: } \\
\text { Fatigue Severity Scale, HADS: Hospital Anxiety and Depression Scale, min: } \\
\text { Minutes, MET: Metabolic equivalent }\end{array}$} \\
\hline
\end{tabular}

Nine (23.7\%) patients had lower normal daytime sleepiness, $16(42.1 \%)$ patients had higher normal daytime sleepiness, $1(2.6 \%)$ patients had mild excessive daytime sleepiness, 4 (10.5\%) patients had moderate excessive daytime sleepiness and 8 (21.1\%) patients had severe excessive daytime sleepiness according to ESS scores (27). In addition, 55.3\% of patients with OSAS had severe fatigue. When we look at the mental state of the patients, $78.9 \%$ of patients had high anxiety level and $63.2 \%$ of patients had high depression level.
A marked correlation were observed between IPAQ-total PA score and ESS score $(r=-0.493, p=0.002)$; HADS-A score $(r=-0.338, p=0.041)$; NHP-social isolation score $(r=-0.406$, $\mathrm{p}=0.013)$; FIS-physical score $(\mathrm{r}=-0.404, \mathrm{p}=0.013)$ and FISpsychosocial score $(r=-0.411, p=0.012)$. IPAQ-moderate PA score was significantly correlated with FIS-physical score $(r=-$ $0.380, \mathrm{p}=0.020)$; FIS-cognitive score $(\mathrm{r}=-0.413, \mathrm{p}=0.011)$; FIS-psychosocial score $(r=-0.411, p=0.012)$ and FIS-total score $(r=-0.418, p=0.010)$. IPAQ-walking PA score was significantly correlated with ESS score $(r=-0.335, p=0.040)$ and NHP-social isolation score $(r=-0.442, p=0.006)$. IPAQ-sitting score was significantly associated with NHP-energy score $(r=-0.406$, $\mathrm{p}=0.019)$; NHP-emotional reactions score $(\mathrm{r}=-0.445, \mathrm{p}=0.010)$ and NHP-total score $(r=-0.516, p=0.002)$. In addition, there were evident correlations between ESS score and NHP-physical mobility score $(r=0.338, p=0.041)$; FOSQ-vigilance $(r=-0.335$, $\mathrm{p}=0.049) ;$ FSS score $(r=0.347, \mathrm{p}=0.038)$; FIS-physical score $(r=0.483, p=0.002)$; FIS-cognitive score $(r=-0.413, p=0.011)$; FIS-psychosocial score $(r=0.429, p=0.008)$ and FIS-total score $(r=0.428, p=0.008)$. There was any correlations between the AHI score and none of parameters $(p>0.05)$.

\section{Discussion}

The main findings of our study are that total amount of PA is closely related with excessive daytime sleepiness, anxiety level, social isolation and effects of fatigue on physical and psychosocial functions in patients with OSAS. The amount of sedentary time is negatively associated with especially energy and emotional reactions dimensions of general quality of life of patients with OSAS. There is any associations between PA level and disease severity determined by $\mathrm{AHI}$ score and functional exercise capacity in newly diagnosed patients.

The PA level of individuals with OSAS was found clearly lower than those of healthy women and men (7) and $32 \%$ of moderate-severe patients were sedentary and $85 \%$ of patients walked less than 10.000 steps/day (8). In accordance with these findings, only nearly $19 \%$ of our patients was sufficiently active and PA level was low. Aerobic exercise capacity was shown to be reduced in few studies that evaluates using the cardiopulmonary exercise testing $(28,29)$ but our patients' exercise capacity was normal according to expected values. These can be explained with that we excluded patients with chronic diseases like arterial or pulmonary hypertension, asthma, COPD that can impair exercise capacity. The evaluation time for our patients was also shortly after the diagnosis. Butner et al. (30) showed that OSA severity has no correlation with exercise capacity. Verwimp et al. (8) reported that low PA level is related with OSAS severity in moderate-severe OSAS. Just the opposite these results, none of PA and 6MWT distance results were associated with disease severity in our study. These can be related that our patients included patients from all disease severities and median $\mathrm{AHI}$ values (median AHI: 26.9 ) of our patients were very lower than those of Verwimp et al. (8) (median AHI: 54). As an expected finding, we showed that total amount of PA level is closely related with excessive daytime sleepiness and physical and psychosocial effects of fatigue. As the effects of fatigue and excessive daytime sleepiness increases, patients with OSAS start to walk and do moderate PAs less. As the evidence increases 
about the relationship between cognitive functions and PA level (31), the correlation between increase in moderate activities level and decrease in effects of fatigue on cognition is an expected and new finding for OSAS.

Fatigue is a common symptom in patients with OSAS and reported by $61 \%$ of patients in one study (5). Present study showed that $55.3 \%$ of patients with OSAS had severe fatigue and $60.5 \%$ of patients reported debility. Hong and Dimsdale (7) showed that PA level of moderate-severe OSAS patients is significantly related with subjective well-being (vitality) regardless of sleep apnea severity or BMI and fatigue perception was negatively correlated with PA. ESS score was significantly related with self-reported complaints (sleepiness, tiredness and lack of energy) but not with fatigue but female patients showed notably association with all of these complaints (5). There was any association between AHI and ESS scores in this present study as indicated in the literature (32). But both fatigue severity and impacts of fatigue on physical, psychosocial and cognitive functions were related with excessive daytime sleepiness. Due to common poor sleep quality and sleep fragmentations in OSAS, increase in fatigue perception and decrease in cognitive functions related with daytime sleepiness are expected situations.

Psychological well-being results showed that $78.9 \%$ of patients had high anxiety level and $63.2 \%$ of patients had high depression level. In spite of newly diagnosed, higher rates of depression and anxiety level can be due to decreased functionality and quality of life as a results of nocturnal hypoxemia, sleep fragmentation, snoring, excessive daytime sleepiness and poor neurocognitive performance. Indeed, most prevalent symptoms that reported by our patients were snoring, forgetfulness and debility. A previous study demonstrated that in spite of above normal thresholds, depression and anxiety levels were not correlated with the AHI score in newly diagnosed OSAS patients (33). But as the anxiety level increases, total PA amount decreases in our patients with different disease severity as a new finding.

Quality of life is weakly or not related with determinants of OSAS severity like AHI and nocturnal hypoxemia $(30,34,35)$. In moderate-severe OSAS, the decrease in quality of life was related with physical functioning and ESS score was found to be correlated with physical and mental domains of quality of life (35). We also found significant association between excessive daytime sleepiness and physical mobility and vigilance dimensions of quality of life. Daytime sleepiness adversely affects quality of life in OSAS by reducing mobility and vigilance. In a study with somnolent moderate-severe OSAS, higher mobility and sleep subdimensions of NHP was related with poor PA level but daytime sleepiness was not related with PA level (8). These can be related with that our AHI scores were lower and most affected dimension of NHP in our patients were emotional reactions, social isolation and sleep according to reported normative data (36). Therefore, as the amount of total PA and walking decreases, social isolation of patients increases according to our data. The median sitting score (5.6 hours) of our patients was higher than reported for general population (37). BMI, daytime sleepiness, exercise self-efficacy, fear of movement, and depressive symptoms were shown to explain only $22.9 \%$ of variance in sedentary time (9). We too didn't find any associations between sedentary time and daytime sleepiness and level of anxiety and depression. A very important consequence of our work was that the quantity of sitting as an indicator of sedentary time is significantly related with energy, emotional reactions dimensions and general quality of life. Any relationship between NHP-sleep dimension with certain parameters can be explain with that questions in this section don't reflect the features of OSAS and contain detailed information about sleep.

\section{Study Limitations}

There are several limitations in this study. First of all, our study is limited by its modest sample size and by exclusion criteria. It is unknown whether our observations would generalize to patients with OSAS with comorbidities like hypertension. Another limitation of our study, we evaluated the patients immediately after diagnosis. It might be better to monitor the long-term outcomes of the patients.

\section{Conclusion}

In conclusion, the present study showed that total amount of PA is closely related with excessive daytime sleepiness, anxiety level, social isolation and effects of fatigue on physical and psychosocial functions in patients with OSAS. The amount of sedentary time is negatively associated with especially energy and emotional reactions dimensions of general quality of life of patients with OSAS. Furthermore, the association between increase in moderate activities level and decrease in effects of fatigue on cognition is a new finding for OSAS.

Acknowledgments: The authors would like to thank the volunteer participants for their aids in the data collection process.

\section{Ethics}

Ethics Committee Approval: This study has been approved by the Ethics Committee of Non-Interventional Research in Hacettepe University (date: 21.06.2018; no: GO 18/491).

Informed Consent: Participants were informed about the study and their written informed consents were collected prior to study.

Peer-review: Internally peer-reviewed.

\section{Authorship Contributions}

Design: H.Ç., N.E., H.A., Data Collection or Processing: H.Ç., N.E., E.Ç.K., M.S., N.V.Y., Analysis or Interpretation: D.I.I.I., H.A., H.F., H.Ç., S.A., Literature Search: H.F., S.A., M.Y.E., H.Ç., N.E., Writing: H.Ç., E.Ç.K., N.E.

Conflict of Interest: No conflict of interest was declared by the authors.

Financial Disclosure: The authors declared that this study received no financial support.

\section{References}

1. Lurie A. Obstructive sleep apnea in adults: epidemiology, clinical presentation, and treatment options. Adv Cardiol 2011;46:1-42.

2. Epstein LJ, Kristo D, Strollo PJ Jr, Friedman N, Malhotra A, Patil SP, Ramar K, Rogers R, Schwab RJ, Weaver EM, Weinstein MD; Adult Obstructive Sleep Apnea Task Force of the American Academy of Sleep Medicine. Clinical guideline for the evaluation, management 
and long-term care of obstructive sleep apnea in adults. J Clin Sleep Med 2009;5:263-76.

3. Chwiesko-Minarowska S, Minarowski L, Kuryliszyn-Moskal A, Chwiesko J, Chyczewska E. Rehabilitation of patients with obstructive sleep apnea syndrome. Int J Rehabil Res 2013;36:291-7.

4. Desplan M, Mercier J, Sabate M, Ninot G, Prefaut C, Dauvilliers Y. A comprehensive rehabilitation program improves disease severity in patients with obstructive sleep apnea syndrome: a pilot randomized controlled study. Sleep Med 2014;15:906-12.

5. Chervin RD. Sleepiness, fatigue, tiredness, and lack of energy in obstructive sleep apnea. Chest 2000;118:372-9.

6. Bardwell WA, Moore P, Ancoli-Israel S, Dimsdale JE. Fatigue in obstructive sleep apnea: driven by depressive symptoms instead of apnea severity? Am J Psychiatry 2003;160:350-5.

7. Hong S, Dimsdale JE. Physical activity and perception of energy and fatigue in obstructive sleep apnea. Med Sci Sports Exerc 2003;35:1088-92.

8. Verwimp J, Ameye L, Bruyneel M. Correlation between sleep parameters, physical activity and quality of life in somnolent moderate to severe obstructive sleep apnea adult patients. Sleep Breath 2013;17:1039-46.

9. Igelstrom $H$, Emtner $M$, Lindberg $E$, Asenlof P. Physical activity and sedentary time in persons with obstructive sleep apnea and overweight enrolled in a randomized controlled trial for enhanced physical activity and healthy eating. Sleep Breath 2013;17:1257-66.

10. Consultation WHOE. Appropriate body-mass index for Asian populations and its implications for policy and intervention strategies. Lancet 2004;363:157-63.

11. Hori T, Sugita Y, Koga E, Shirakawa S, Inoue K, Uchida S, Kuwahara H, Kousaka M, Kobayashi T, Tsuji Y, Terashima M, Fukuda K, Fukuda $\mathrm{N}$; Sleep Computing Committee of the Japanese Society of Sleep Research Society. Proposed supplements and amendments to 'A Manual of Standardized Terminology, Techniques and Scoring System for Sleep Stages of Human Subjects', the Rechtschaffen \& Kales (1968) standard. Psychiatry Clin Neurosci 2001;55:305-10.

12. Sleep-related breathing disorders in adults: recommendations for syndrome definition and measurement techniques in clinical research. The Report of an American Academy of Sleep Medicine Task Force. Sleep 1999;22:667-89.

13. Kushida CA, Littner MR, Morgenthaler T, Alessi CA, Bailey D, Coleman J Jr, Friedman L, Hirshkowitz M, Kapen S, Kramer M, Lee-Chiong T, Loube DL, Owens J, Pancer JP, Wise M. Practice parameters for the indications for polysomnography and related procedures: an update for 2005. Sleep 2005;28:499-521.

14. Medicine ACoS. ACSM's Health-Related Physical Fitness Assesment Manual 4th ed. ed. China: Lippincott Williams\&Wilkins; 2014.

15. Durnin JV, Womersley J. Body fat assessed from total body density and its estimation from skinfold thickness: measurements on 481 men and women aged from 16 to 72 years. Br J Nutr 1974;32:77-97.

16. Saglam M, Arikan H, Savci S, Inal-Ince D, Bosnak-Guclu M, Karabulut E, Tokgozoglu L. International physical activity questionnaire: reliability and validity of the Turkish version. Percept Mot Skills 2010;111:278-84.

17. Singh SJ, Puhan MA, Andrianopoulos V, Hernandes NA, Mitchell KE, Hill C], Lee AL, Camillo CA, Troosters T, Spruit MA, Carlin BW, Wanger J, Pepin V, Saey D, Pitta F, Kaminsky DA, McCormack MC, Maclntyre N, Culver BH, Sciurba FC, Revill SM, Delafosse V, Holland AE. An official systematic review of the European Respiratory Society/ American Thoracic Society: measurement properties of field walking tests in chronic respiratory disease. Eur Respir J 2014;44:1447-78.

18. Kucukdeveci AA, McKenna SP, Kutlay S, Gursel Y, Whalley D, Arasil T. The development and psychometric assessment of the Turkish version of the Nottingham Health Profile. Int J Rehabil Res 2000;23:31-8.
19. Izci B, Firat H, Ardic S, Kokturk O, Gelir E, Altinors M. Adaptation of functional outcomes of sleep questionnaire (FOSQ) to Turkish population. Tuberk Toraks 2004;52:224-30.

20. Izci B, Ardic S, Firat H, Sahin A, Altinors M, Karacan I. Reliability and validity studies of the Turkish version of the Epworth Sleepiness Scale. Sleep Breath 2008;12:161-8.

21. Theander K, Cliffordson C, Torstensson O, Jakobsson P, Unosson M. Fatigue Impact Scale: Its validation in patients with chronic obstructive pulmonary disease. Psychol Health Med 2007;12:470-84.

22. Armutlu K, Korkmaz NC, Keser I, Sumbuloglu V, Akbiyik DI, Guney Z, Karabudak R. The validity and reliability of the Fatigue Severity Scale in Turkish multiple sclerosis patients. Int J Rehabil Res 2007;30:81-5.

23. Aydemir Ö GT, Küey L, Kültür S. Hastane Anksiyete ve Depresyon Ölçeği Türkçe Formunun Geçerlilik ve Güvenilirlik Çalışması. Türk Psikiyatri Dergi 1997;8:280-7.

24. Green SB, Salkind NJ. Using SPSS for Windows and Macintosh: Analyzing and Understanding Data. 7th ed. United States of America: Pearson; 2013.

25. Hayran M, Hayran M. Sağlık Araştırmaları lçin Temel Istatistik. 1st ed. Ankara: Omega Yayınları; 2011.

26. Domholdt E. Physical Therapy Research: Principles and Applications. 2nd ed. Philadelphia: WB Saunders; 2000.

27. Johns MW. What Is Excessive Daytime Sleepiness? In: Fulke P, Vaughan S, editor. Sleep Deprivation: Causes, Effects and Treatment New York: Nova Science Inc; 2009. p. 59-94.

28. Beitler JR, Awad KM, Bakker JP, Edwards BA, DeYoung P, Djonlagic I, Forman DE, Quan SF, Malhotra A. Obstructive sleep apnea is associated with impaired exercise capacity: a cross-sectional study. J Clin Sleep Med 2014;10:1199-204.

29. Ucok K, Aycicek A, Sezer M, Genc A, Akkaya M, Caglar V, Fidan F, Unlu M. Aerobic and anaerobic exercise capacities in obstructive sleep apnea and associations with subcutaneous fat distributions. Lung 2009; 187:29-36.

30. Butner KL, Hargens TA, Kaleth AS, Miller LE, Zedalis D, Herbert WG. Association of Obstructive Sleep Apnea Severity with Exercise Capacity and Health-related Quality of Life. N Am J Med Sci 2013;5:362-6.

31. Haskell WL, Lee IM, Pate RR, Powell KE, Blair SN, Franklin BA, Macera CA, Heath GW, Thompson PD, Bauman A; American College of Sports Medicine; American Heart Association. Physical activity and public health: updated recommendation for adults from the American College of Sports Medicine and the American Heart Association. Circulation 2007;116:1081-93.

32. Sauter C, Asenbaum S, Popovic R, Bauer H, Lamm C, Klosch G, Zeitlhofer J. Excessive daytime sleepiness in patients suffering from different levels of obstructive sleep apnoea syndrome. I Sleep Res 2000;9:293-301.

33. Macey PM WM, Kumar R, Cross RL, Harper RM. . Relationship between Obstructive Sleep Apnea Severity and Sleep, Depression and Anxiety Symptoms in Newly-Diagnosed Patients. PLoS ONE 2010;5:e10211.

34. Sforza E, Janssens JP, Rochat T, Ibanez V. Determinants of altered quality of life in patients with sleep-related breathing disorders. Eur Respir J 2003;21:682-7.

35. Asghari A, Mohammadi F, Kamrava SK, Jalessi M, Farhadi M. Evaluation of quality of life in patients with obstructive sleep apnea. Eur Arch Otorhinolaryngol 2013;270:1131-6.

36. Ogutmen B, Yildirim A, Sever MS, Bozfakioglu S, Ataman R, Erek $E$, Cetin $O$, Emel A. Health-related quality of life after kidney transplantation in comparison intermittent hemodialysis, peritoneal dialysis, and normal controls. Transplant Proc 2006;38:419-21.

37. Bauman A, Ainsworth BE, Sallis JF, Hagstromer M, Craig CL, Bull FC, Pratt M, Venugopal K, Chau J, Sjöström M; IPS Group. The descriptive epidemiology of sitting. A 20-country comparison using the International Physical Activity Questionnaire (IPAQ). Am J Prev Med 2011;41:228-35. 